\title{
Infiltration Galleries:-A Solution To Drinking Water Supply For Urban Areas Near Rivers."
}

\author{
Er. Rajvir Singh Jurel ${ }^{1}$, Er. Raj Bahadur Singh ${ }^{2}$, Dr. Sunit Kumar Jurel ${ }^{3}$, Dr. \\ Raghuwar D.Singh ${ }^{3}$ \\ ${ }^{1}$ Formerly Chief Engineer, Minor Irrigation, lucknow (u.p) presently working as Senior Faculty in Department \\ of civil engineering, Hindustan college of Science and technology, Farah, Mathura, Uttar Pradesh, India \\ ${ }^{2}$ Superintending engineer Department of Minor Irrigation, Bareilly, Uttar Pradesh, India \\ ${ }^{3}$ Department of Prosthodontics, faculty of dental sciences, King George Medical University, Lucknow Uttar \\ Pradesh, India
}

\begin{abstract}
Most of the big cities are situated on river banks and are dependent on river water for drinking purpose, which is supplied after treatment, to inhabitants.Due to pollution and sewerage disposed in the river, the quality of water has become poor and the treatment cost has gone up. During summer the quantity of water flowing in the river is very less on account of which concentration of impurities is also more. On the other hand due to over exploitation of ground water for irrigation, the ground water table is also going down at fast rate, hence availability of ground water is also not certain. The quality of ground water is also becoming poor due to pollution, intrusion of brackish/saline water, and concentration of fluoride etc. If system of infiltration galleries ${ }^{1}$ is provided in the bed of the river at 5 to $10 \mathrm{~m}$ below bed level, by means of perforated pipes (Strainer) the availability of water in terms of quality and quantity will improve. Hence a solution to drinking water supply for major cities has been presented in this article, along with a typical example for design of infiltration gallery for Agra City (U.P.,India) .
\end{abstract}

Keywords - Brackish Water; Drinking Water Supply, Infiltration Gallery;

\section{Introduction}

Water is indispensable for the survival of human, animal, and plant life. It is used for variety of purposes like drinking, washing, irrigation, industry, hydroelectric - power - generation, navigation etc. Water is inexhaustible natural resource and it constitutes the basic element, without which life on earth is not possible. Water occurs in nature as solid, liquid, and gaseous form.

The availability of a water supply adequate in terms of both quality and quantity is essential to human existence. Early people recognized the importance of water from a quantity view point. Civilization developed around of water bodies that could support agriculture and transportation as well as provide drinking water. "The quantity of water on earth ${ }^{2}$ is fixed and is estimated to be 1,38,550 B.ham (Billion hectare metre), out of which $1,34,800$ B.ham, which is $97.3 \%$ is contained in oceans, as salty water. The quantity of fresh water on earth is only 3750 B.ham, which is only $2.7 \%$. Even out of this $2.7 \%$ fresh water, about $2.03 \%$ is contained as polar ice and glaciers, and $0.61 \%$ is ground water. Out of this $0.61 \%$ ground water the exploitable ground water up to $800 \mathrm{~m}$ depth below ground is only $0.27 \%$. Fresh available surface water in river and lakes is only $0.01 \%$.

It is clear from above that available fresh surface water is only $0.01 \%$ and fresh utilizable ground water is only $0.27 \%$ of the total water available on earth. This shows the scarcity of fresh water on earth. On account of increasing population the demand for fresh water is increasing at rapid rate and the sources of fresh water are decreasing. As per "Water and Related Statistics"3 Published by Central water commission New Delhi in the month of May 2004 availability of internal renewable fresh water resources in India is only $190.8 \mathrm{M}$ ham.

India is having only $4 \%$ of the world's average annual supplies of $4.70 \mathrm{~B}$-ham, while its population is $16 \%$ of the world population, which shows how much stress is there on fresh water resources in India. Due to excessive drawl of ground water in some areas, the ground water table is going down at fast rate and shallow tube wells are going dry. Some areas around river Yamuna from Delhi to Agra are having brackish/saline water which cannot be used for drinking as well as for irrigation. The sources of drinking water supplies are Reservoirs, Lakes, Rivers which depend on surface flow of water and tube wells which are dependent on ground water.

\section{Water Treatment Process-}

The following is the treatment process for drinking water supply from rivers-

1. Aeration - Removes undesirable gases and /or oxidation of Iron and Manganese.

2. Sedimentation - used for solid separation 
3. Coagulation - Agglomeration of small suspended particles into groups.

4. Flocculation - increasing the effective size for settling.

5. Softening -Removes calcium and /or magnesium hardness.

6. Filtration - Removes residual $\mathrm{CaCo}$, Crystals and $\mathrm{Mg}(\mathrm{OH}) 2$ floc left over from softening.

7. Disinfection - Destroys pathogens, enough chlorine added to provide a residues in the distribution system.

8. Storage - Provide contact time for disinfection and stores water for peak demands.

Hence normal drinking water purification system consists of 8 steps for river as source. In case of water supply from infiltration galleries, first 6 steps are not required and only two steps of disinfection and storage are required. In other words the water received from infiltration galleries is comparable with ground water.

\section{Need For Infiltration Gallery -}

In urban areas along rivers drinking water supply is mainly dependent upon river. Due to pollution the quality of water in these rivers has gone down and in few areas it is so much polluted due to which water is not even fit for irrigation. The surface flow of these rivers is negligible in summer on account of which required amount of water is not available from the month of January to June every year.

Hence there is problem of quality as well as of quantity of available drinking water. An adequate supply of pure water is absolutely essential to human existence. The consequence of contaminated water supply results in outbreak of water Borne diseases like Cholera and Typhoid.

One of the most suitable solution for getting drinking water at low cost and throughout the year is provision of "Infiltration Galleries" in the river bed which will provide clean filtered water continuously even in summer. ${ }^{2,4}$

\section{Infiltration Galleries-}

Infiltration galleries are permeable horizontal or inclined conduits into which water can infiltrate from an overlying or adjacent source. They are constructed below the water table in an area where there is sufficient recharge to offset the pumping rate and where the permeability of the soil is sufficient to transmit the quantity of water to the existing gallery under the existing head conditions.

For getting water from infiltration galleries for drinking purpose, perforated pipes will be laid below the river bed at a depth about 5 to $10 \mathrm{~m}$ from bed level. These pipes will be connected to a sump-well in which filtered water will flow under gravity due to head of water about it. This stored water after disinfection treatment will be supplied for drinking purpose. The concept of infiltration gallery is that when water passes through the bed of river which has sand with filter, it is filtered and even when there is negligible surface flow in the river, there is always sub surface flow in the permeable strata of sand below the bed of river, Hence we get filtered water continuously.

The performance of Infiltration galleries has been studied by Alvaro Camacho ${ }^{5}$ and following conclusions have been drawn:-

"Infiltration galleries built in the permeable alluvial deposits of the rivers can be suitable systems for improving water quality from surface waters. Removal ratios of more than 90 percent for turbidity, SS, and $F C$ have been recorded (during this research project). Infiltration galleries produce high-quality and stable volumes of water independent of seasonal variations in the quality and quantity of raw surface stream, minimizing environmental effects.

It seems that there is a natural and self-cleaning filtration process at work here. The permeable deposits of the Parapeti River form a highly efficient system for the pretreatment of water that contains high concentrations of solids. Moreover, the filtration qualities of the deposits are constantly maintained by the action of the river itself: during periods of flooding, the top layer of filtration material - the coarse sand - is stirred-up and cleaned by the sheer force of water flow. As flooding subsides, the clean, loose sand re-settles on the river bed, thus preventing the natural process of clogging and hardening, which would otherwise impair its efficacy as a filter. It is, therefore, possible that the natural composition of the river deposits, assisted by the cycle of the river itself, are acting as an effective and self-cleaning filter of the solids contained in the river.

With proper studies and depending on local conditions and the characteristics of raw-water quality, infiltration galleries are a suitable alternative for supplying drinking water to small and medium communities, with minimum capital costs and lower O\&M costs. The system in Camiri has been running since the early 1980s, and no critical O\&M problems have been observed (particularly clogging). It is essential that galleries must have easy access to facilitate the periodic cleaning of sediments from conduits (the minimum channel section should be $1.0 \times 1.0 \mathrm{~m}$ or more for manual cleaning). The infiltration gallery system in Camiri has shown that the amount of maintenance required

on the galleries is very small indeed. For this reason, as well as the benefits of improved or maintained water quality, infiltration galleries have a significant advantage over other conventional systems". 
From above it is clear that a proposal of drinking water supply through infiltration galleries should work well for cities situated on river bank.

The concept and benefits of infiltration galleries for city water supply will be further clear from a typical example given below for proposed water supply for Agra.

\section{TYPICAL PROPOSAL FOR CITY WATER SUPPLY OF AGRA CITY - THROUGH} INFILTRATION GALLERIES:-

Agra City is famous for "TAJMAHAL" the seventh wonder of world. Large number of tourists from India and abroad come to see this "Monument of Love" But the drinking water supply is a big problem for this city. The reasons are given below:

(i) The ground water is brackish/highly saline and also contains fluoride; hence drinking water supply from Tube wells is not feasible.

(ii) The quality of Yamuna River water, which is the main source of water supply for the city is poor as is clear from the Table-1.

On account of this poor quality of raw water, the treatment cost is high.

(iii) The quantity of water flowing in the river during the summer season is negligible.

(iv) The ground water table is going down at fast rate due to over exploitation of ground water for irrigation in this district.

(v) The top layer of soil is clayey up to about $15-18 \mathrm{~m}$, on account of which recharge of ground water is unsatisfactory as rain water flows down to river and then to sea during monsoons.

(vi) The river Yamuna is effluent, as it is taking water from aquifer, affecting availability of ground water.

(vii) The flow of ground water is towards Yamuna and Chambal River.

At present the city is getting water supply from river Yamuna by providing water treatment plant at Sikandra and Near Jivani Mandi (Known as Water Works).

One of the solutions to this problem is construction of "INFILTRATION GALLERY" under the bed of river Yamuna at different places. To start with this a pilot project can be taken up on the downstream of sikandara water works and after the success of this pilot project, more number of galleries can be provided.

A typical drawing for Infiltration Gallery for Yamuna River at Agra has been shown in Figure- 1. In this 10 No's of plain PVC Pipe of $200 \mathrm{~mm}$ internal dia, $10 \mathrm{~mm}$ thick for a length of $200 \mathrm{~m}$ each, along with 10 No's of $200 \mathrm{~mm}$ internal diameters PVC strainer having ribs on outer surface and horizontal slots of $1 \mathrm{~mm}$ thickness each, with 8 percent open area for alength of $300 \mathrm{~m}$ have been provided. The plain PVC pipe (CM casing pipe) and ribbed PVC Screen are as per IS 12818/92 " Indian Standard on UNPLASTICIZED PVC SCREEN AND CASING PIPES FOR BORE/TUBE WELL SPECIFICATION." "

The pipes and screens placed $5 \mathrm{~m}$ below bed of river Yamuna. The R.L. of different points at site are given below-

R.L. of Bed of river Yamuna $\quad=150.1 \mathrm{~m}$

R.L. of minimum Water level in Yamuna $=152.2 \mathrm{~m}$

R.L. of high flood level of river Yamuna $=161.7 \mathrm{~m}$

R.L. of Top of sump well $\quad=163.0 \mathrm{~m}$

R.L. of Bottom of Sump well $\quad=143.0 \mathrm{~m}$

R.L. of centre line of strainer $\quad=145.1 \mathrm{~m}$

The strainer will be covered with 2-4 mm P. gravel all around. After this a layer of coarse sand $2.0 \mathrm{~m}$ thickness will be placed. Over this coarse sand, the natural Yamuna sand will be placed for $2.50 \mathrm{~m}$ depth. The pit will be excavated at 1:3 (H:V) Slope and the work will be done in the month of summer so that laying of pipes is possible. If required dewatering may be done by pumping out water through bore wells at required spacing on up stream side of the site.

The coefficient of permeability of different materials is as given below:

For P. gravel K $=1 \times 10^{-1} \mathrm{~m} / \mathrm{sec}$

For Course Send $\mathrm{K}=4 \times 10^{-4} \mathrm{~m} / \mathrm{sec}$

For Yamuna Sand $\mathrm{K}=2 \times 10^{-4} \mathrm{~m} / \mathrm{sec}$

The average vertical permeability of this deposit will be

$$
\begin{gathered}
\mathrm{K}_{\mathrm{V}}=\underset{\frac{\mathrm{H} 1}{\mathrm{~K} 1}+\frac{\mathrm{H} 2}{\mathrm{~K} 2}+\frac{\mathrm{H} 3}{\mathrm{~K} 3}}{\text { Where } \mathrm{H}=5.0 \mathrm{~m} \quad \mathrm{~K}_{1}=2 \times 10^{-4} \mathrm{~m} / \mathrm{sec}} \\
\mathrm{H}_{1}=2.5 \mathrm{~m} \quad \& \quad \mathrm{~K}_{2}=4 \times 10^{-4} \mathrm{~m} / \mathrm{sec}
\end{gathered}
$$


Hence

$$
\mathrm{H}_{3}=0.50 \mathrm{~m} \quad \& \quad \mathrm{~K}_{3}=1 \times 10^{-1} \mathrm{~m} / \mathrm{sec}
$$

$\mathrm{K}_{\mathrm{V}}=2.86 \times 10^{-4} \mathrm{~m} / \mathrm{sec}$

The Strainer assembly will have minimum head of $(152.50-145.10 \mathrm{~m})=7.1 \mathrm{~m}$. of Water and Maximum of $(161.70-145.10 \mathrm{M})=16.60 \mathrm{~m}$. of Water.

The Available Discharge of filtered water by the assembly will be

$$
\mathrm{Q}=\mathrm{k} \text {.i.a }
$$

Where $\mathrm{K}=$ Average Vertical Coefficient of Permeability

$\mathrm{i}=\mathrm{H} / \mathrm{L}$

$$
=2.86 \times 10^{-4} \mathrm{~m} / \mathrm{sec}
$$

$\mathrm{H}=$ Head of Water Which is Minimum of 7.10 M. and maximum of $16.60 \mathrm{M}$.

$\mathrm{L}=$ Length of passage of water

$=5.0 \mathrm{M}$ from bed of river to central line of assembly.

Hence, Min. $\mathrm{i}=7.1 / 5=1.42$

$$
\text { Max. } i=16.6 / 5=3.32
$$

$\mathrm{A}=$ Area of Flow of Water ( $8 \%$ of Strainer Pipe)

$\mathrm{A}=\pi \times 0.22 \times 300 \times 0.08 \times 10$

$$
=165.80 \mathrm{~m}^{2}
$$

Minimum Discharge $=2.86 \times 10^{-4} \times 1.42 \times 165.80$

$$
\begin{aligned}
& =0.0673 \mathrm{Cum} . / \mathrm{Sec} . \\
& =67.30 \mathrm{Lit} . / \mathrm{Sec} . \\
& =48456.0 \text { Gallons per Hour. }
\end{aligned}
$$

Maximum Discharge $=2.86 \times 10^{-4} \times 3.32 \times 165.80$

$$
\begin{aligned}
& =0.1574 \mathrm{Cum} . / \mathrm{Sec} \\
& =157.40 \mathrm{Lit} . / \mathrm{Sec} . \\
& =1,13,328 \text { Gallons } / \mathrm{Hr} .
\end{aligned}
$$

Providing a R.C.C. Sump Well of $6.0 \mathrm{~m}$. of internal dia. and $20 \mathrm{~m}$. Depth, Having freeboard of $1.3 \mathrm{~m}$ above H.F.L.

The Capacity of Well is:

$$
\begin{aligned}
& =\pi \times((6 \times 6) / 4) \times 18.2 \mathrm{Cum} . \\
& =514.35 \mathrm{Cum} .
\end{aligned}
$$

Hence the Sump Well Will be able to store 514.35Cum.of Water.

The Minimum Capacity of Sump Well Will be :

$$
\begin{aligned}
& =\pi \times((6 \times 6) / 4) \times 8.7 \\
& =245.86 \mathrm{Cum} .
\end{aligned}
$$

The arrangement will provide 48,456 to 1,13,328 gallons of filtered water per hour continuously. Such galleries can be made at different places in the river. The depth of strainer, length of strainer, No's of pipes will depend on the site conditions. If required the cleaning of filter can be done by sending compressed air through pipes.

\section{Conclusion:}

Infiltration galleries can provide a cheaper solution for getting filtered water continuously for drinking purposes for cities situated on river banks. By provision of Infiltration galleries treatment cost will be reduced and we can have adequate drinking water in quality and quantity even in summer when practically no water is flowing on the bed of river.

\section{References}

[1] Project on rain water harvesting and ground water recharge of Agra District (U.P.), to augment drinking water supply - May 2005 Submitted by R.S. JUREL Chief Engineer Minor Irrigation (U.P.)

[2] Amartya kumar bhattacharya . Artificial ground water recharge with a special reference to india.

[3] Central water commission New delhi - water and related statistics. May 2004.

[4] Ray, C., G. Melin, and R.B. Linsky, editors (2002). Riverbank Filtration Improving Source-Water Quality, Kluwer Academic Publishers, Dordrecht.

[5] Evaluation of the existing performance of infiltration galleries in alluvial deposits of the parapeti river by Diploma Engineer Alvaro Camacho , Bolivian Association of Sanitary Engineers Casilla 9348 La Paz, Bolivia.

[6] Indian Standard on "Unplasticized PVC Screen and casting Pipes for Bore / Tubewell - Specification IS 12818/1992. 


\section{Figure Legends}

Fig.1 Drawing Of Infiltration Gallery

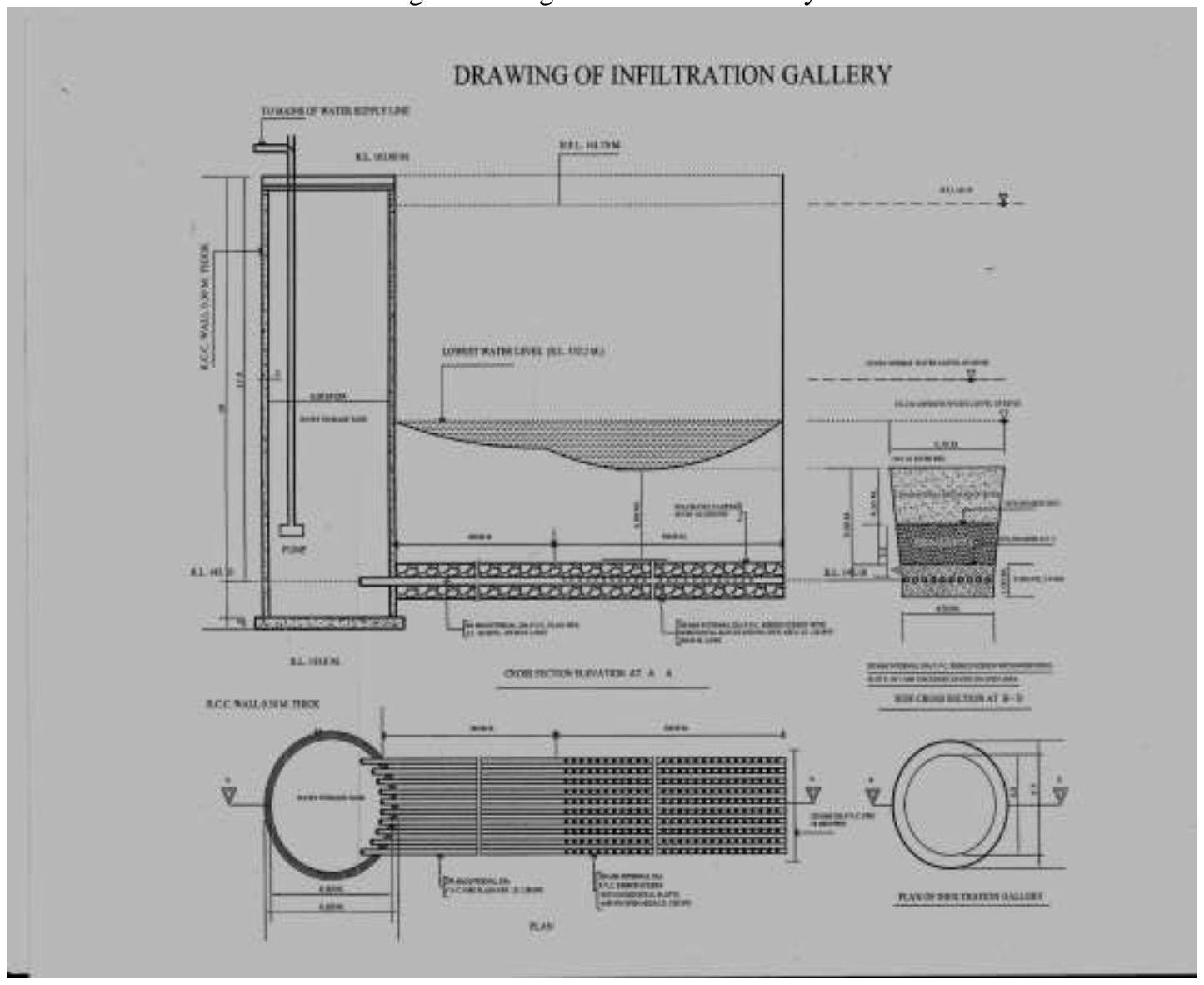

Table Legends

Table -1

\begin{tabular}{|c|c|c|c|c|}
\hline $\begin{array}{c}\text { Sr. } \\
\text { No. }\end{array}$ & Item & $\begin{array}{c}\text { Quality of raw water of } \\
\text { Yamuna at Agra }\end{array}$ & $\begin{array}{c}\text { Norms as } \\
\text { recommended } \\
\text { by Central } \\
\text { Pollution } \\
\text { Control Board }\end{array}$ & $\begin{array}{c}\text { Pollution } \\
\text { as } \\
\text { compared } \\
\text { to Norms }\end{array}$ \\
\hline 1 & Colour (Haizon Unit) & $300-900$ & 300 & $\begin{array}{c}3 \text { times } \\
\text { more }\end{array}$ \\
\hline 2 & $\begin{array}{c}\text { Biochemical oxygen Demand } \\
\text { (BOD) }\end{array}$ & $5.0-35.0$ & 3.0 & $\begin{array}{c}12 \text { times } \\
\text { more }\end{array}$ \\
\hline 3 & P.H. & $7.8-9.5$ & $6.5-8.5$ & $\begin{array}{c}1 \text { point } \\
\text { more }\end{array}$ \\
\hline 4 & $\begin{array}{c}\text { Chemical oxygen demand } \\
\text { (COD) }\end{array}$ & $38-110$ & 10 & $\begin{array}{c}11 \text { times } \\
\text { more }\end{array}$ \\
\hline 5 & $\begin{array}{c}\text { Disolved Oxygen } \\
\text { M.P.N. Index per 100 ml. }\end{array}$ & $4-12 \mathrm{mg} / \mathrm{L}$ minimum & $4 \mathrm{mg} / \mathrm{L}$ & $\begin{array}{c}\text { Less by } 4 \\
\text { mg/L }\end{array}$ \\
\hline 6 & $\begin{array}{c}\text { M } 10^{4}-240 \times 10^{4} \\
\text { times } \\
\text { more }\end{array}$ \\
\hline 7 & Fikal coliform per 100 ml. & $11 \times 10^{3}-18 \times 10^{3}$ & 5000 & $\begin{array}{c}9 \text { times } \\
\text { more }\end{array}$ \\
\hline 8 & Total Anomical Nitrogen & $4.4-40.0$ & 1.0 & $\begin{array}{c}40 \text { times } \\
\text { more }\end{array}$ \\
\hline
\end{tabular}

